\title{
A Financial Analysis of IDBI Bank
}

\author{
Dr. O.P Gupta ${ }^{1}$, Sandeep Vyas ${ }^{2}$ \\ ${ }^{1}$ Associate Professor Department of ABST University of Rajasthan Jaipur \\ ${ }^{2}$ Assistant Professor International School of Informatics and Management Jaipur
}

\begin{abstract}
Banks in a financial system play the important role of financial intermediation. It is the banking sector that forms the basis of financial institutionalization in a country and transforms savings into investments. Banks pool savings from fund surplus sources mainly households and allocate to the government and industries thereby effectively allocating savings for domestic capital formation. Banks in this way also offer risk free investment avenue for depositors. The paper focuses on the financial analysis of IDBI Bank which merged with its DFI (Development Financial Institution) unit in the post liberalization period with a view to ascertain whether the financial sector reforms have adversely affected the functioning of the Bank.
\end{abstract}

Key words: DFI (Development Financial Institution), Capital Adequacy Ratio, NPA (Non Performing Asset), Share Capital, Net Worth, Resource Mobilization, Profit after Tax.

\section{Introduction}

The Industrial Development Bank of India (IDBI) was established on 1 July 1964 by an Act of Parliament as a wholly owned subsidiary of the Reserve Bank of India. The ownership of IDBI was transferred to the Government of India on 16 February 1976, and it was made the principal financial institution for coordinating the activities of institutions engaged in financing, promoting and developing industry in the country. After its transformation into a commercial bank the bank has access to low cost funds in the form of current account and savings account.

\section{Purpose of the study}

This study has been conducted with a view to ascertain the financial status of IDBI Bank by analyzing financial statements of the bank. Key financial indicators including balance sheet, net worth, NPAs and PAT have been analyzed. The study is conducted on the basis of secondary data collected from the annual financial reports of the Bank from 2008 to 2013.

\section{Financial analysis of IDBI Bank}

In the financial analysis of the bank, analysis of share capital and other financial measures like NPA levels and the gap between income and profits have been studied. There has been a gap in the income and profit levels due to debt servicing by the IDBI.

Share capital of IDBI Bank

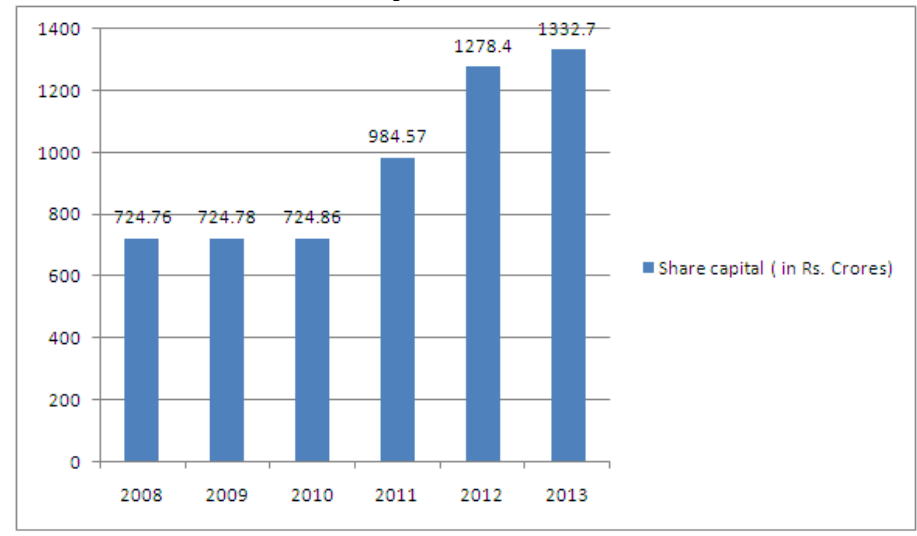

Table 1.1 (a) Share capital of IDBI

\section{Source: IDBI Annual Reports 2008-13}

The IDBI Bank Ltd. recorded an equity share capital of Rs. 1,332.7 crores as on $31^{\text {st }}$ March 2013. While in the previous year it stood at Rs. 1278.4 crores. There has been an increase in the equity share capital by 
54.3 crores. In 2008 the share capital of the bank was 724.26 crore Rupees and remained more or less unchanged till 2011.

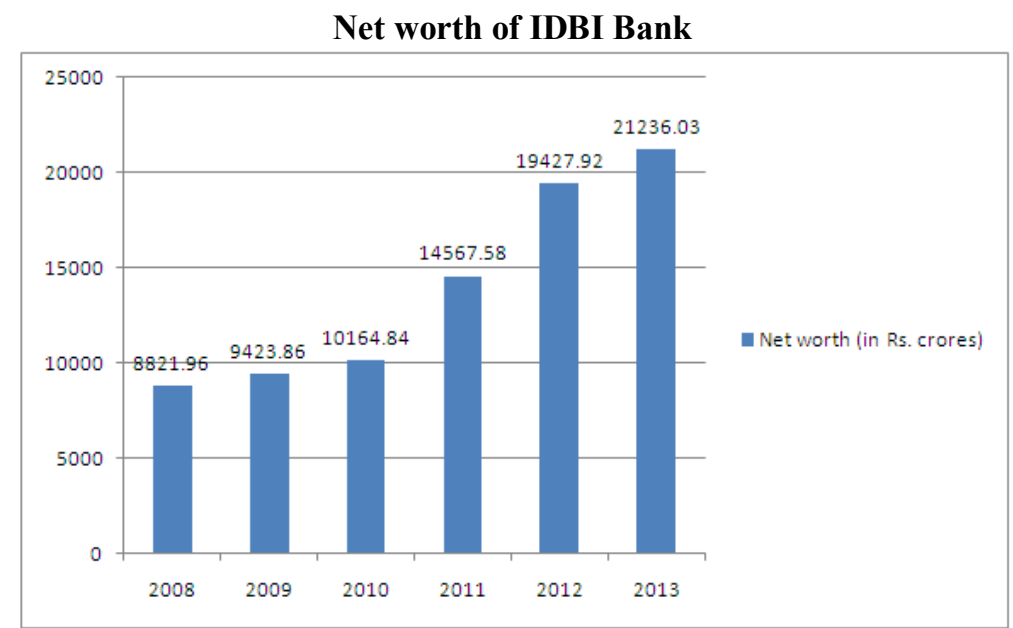

Table 1.1 (b) Net worth of IDBI

\section{Source: IDBI Annual Reports 2008-13}

The net worth of IDBI Bank on $31^{\text {st }}$ March 2008 stood at 8,821.96 crores which increased to 9423.86 crores in 2009, it further increased to 10,164.84 crores in 2010. The increasing trend continued further in 2011 as well with increase in net worth to $14,567.58$ crores. In 2012, it increased to $19,427.92$ crores and on $31^{\text {st }}$ March 2013 it increased to 21,236.03 crores. The increasing trend in the net worth of IDBI Bank during the last five years shows the good financial position of the Bank. In terms of percentage, the net worth of IDBI Bank has recorded an increase of 140.71 percent during the last five years.

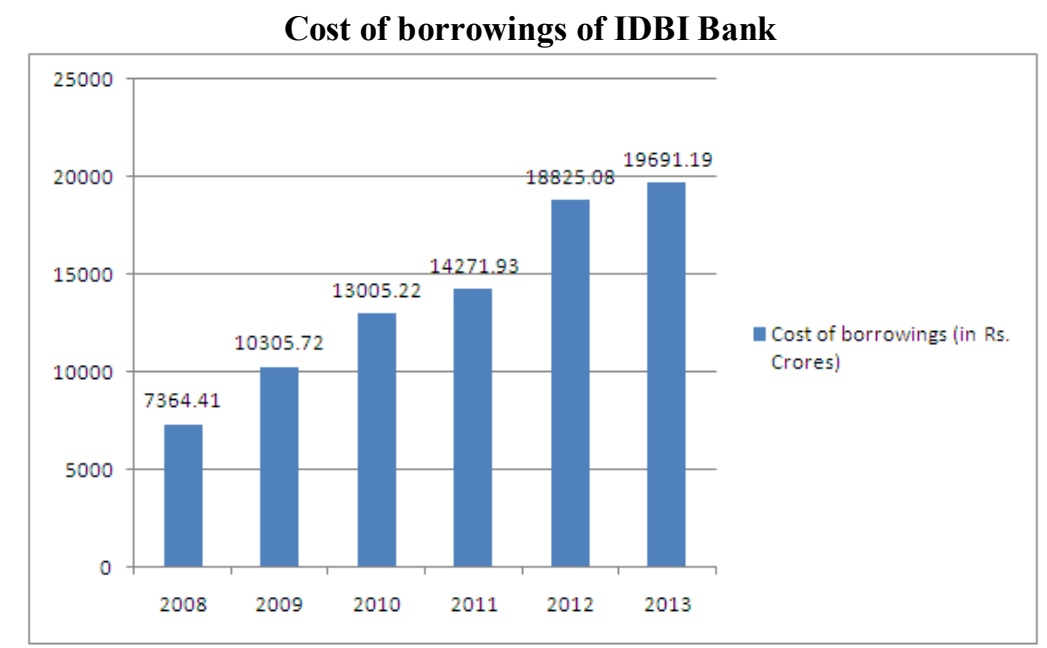

Table 1.1 (c) Cost of borrowings of IDBI

\section{Source: IDBI Annual Reports 2008-13}

The cost of borrowings of IDBI Bank on $31^{\text {st }}$ March 2008 was 7,364.41 crores which increased to $10,305.72$ crores in 2009. It further increased to $13,005.22$ crores in 2010. The cost of borrowings again increased to $14,271.93$ crores in 2011. The cost of borrowings further increased to $18,825.08$ crores in 2012 and again showed an increasing trend in 2013 with the 19,691.19 crores in 2013. In terms of percentage the cost of borrowings of the Bank has increased to 167.38 percent during the last five years. 


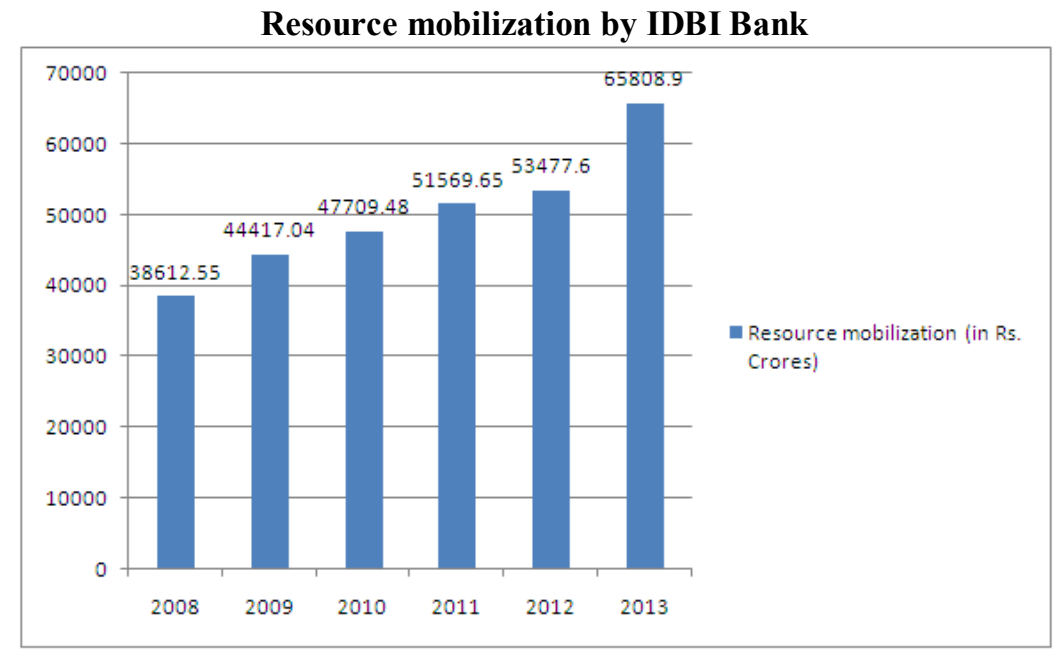

Table 1.1 (d) Resource mobilization of IDBI

\section{Source: IDBI Annual Reports 2008-13}

The borrowings of IDBI Bank were Rs. 38,612.55 crores in 2008 which increased to 44,417.04 crores in 2009. The borrowings further in creased to Rs. $47,709.48$ crores in 2010. In the next year of 2011, the borrowings again increased to $51,569.65$ crores. In 2012, the borrowings further increased to 53,477.6 crores. In 2013 , the borrowings sharply rose to $65,808.9$ crores. In percentage terms, the borrowings have increased to 70.43 percent during the last five years.

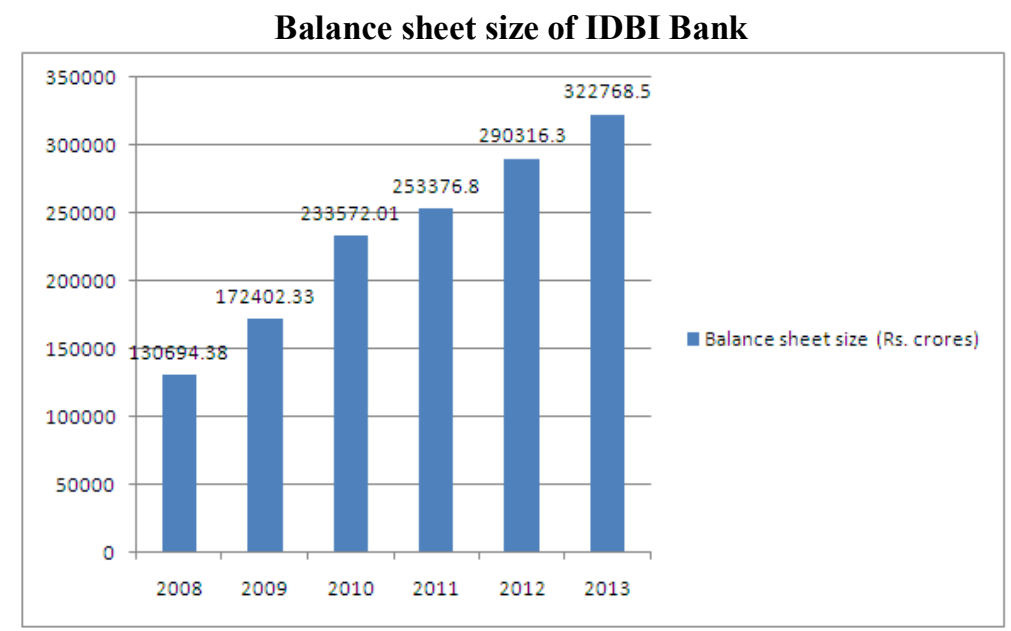

Table 1.1 (e) Balance sheet size of IDBI Bank

\section{Source: IDBI Annual Reports 2008-13}

From the balance sheet of IDBI Bank it can be observed that the total assets of the bank stood at 3,22,768.5 crores on $31^{\text {st }}$ March 2013 while it was 2,90,316.3 crores in the previous year 2012. There has been an increase in assets value by 32.452 crores in the current year. The value of total assets in 2008 was Rs. $130,694.38$ crores which increased to Rs. $172,402.33$ crores in 2009 . In the next year in 2010 it increased further to $233,572.01$ crores. In the next year in 2011 , the increasing trend was maintained and the assets value reached to $253,376.80$ crores. The increase in the value of assets has increase throughout the period from 2008-2013. It shows robust growth of the bank during the period. 


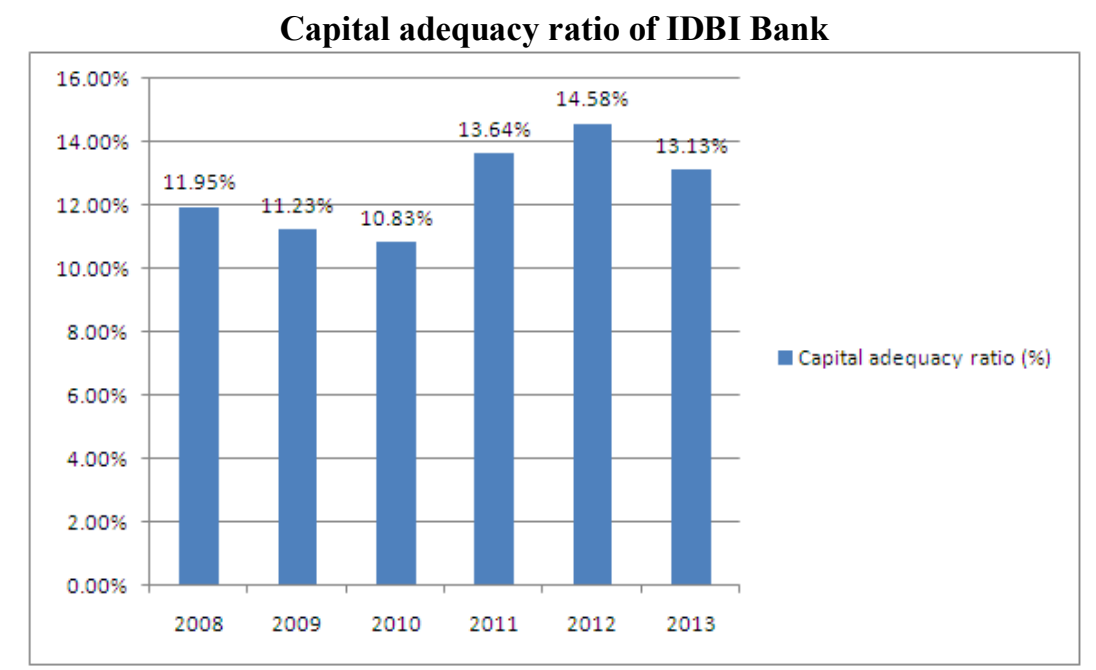

Table 1.1 (f) Capital adequacy ratio of IDBI Bank

\section{Source: IDBI Annual Reports 2008-13}

The CAR of IDBI Bank was $13.13 \%$ in the current year of 2013. The minimum CAR as per the RBI is $9 \%$. The ratio is at comfortable level. Though in the previous year of 2012 it was $14.58 \%$, it declined to $13.13 \%$ but still it is at comfortable level. In 2008, the CAR was $11.95 \%$ which decline to $11.23 \%$ in 2009. It further came down to $10.83 \%$ in 2010 and again increased to $13.64 \%$ in 2011 .

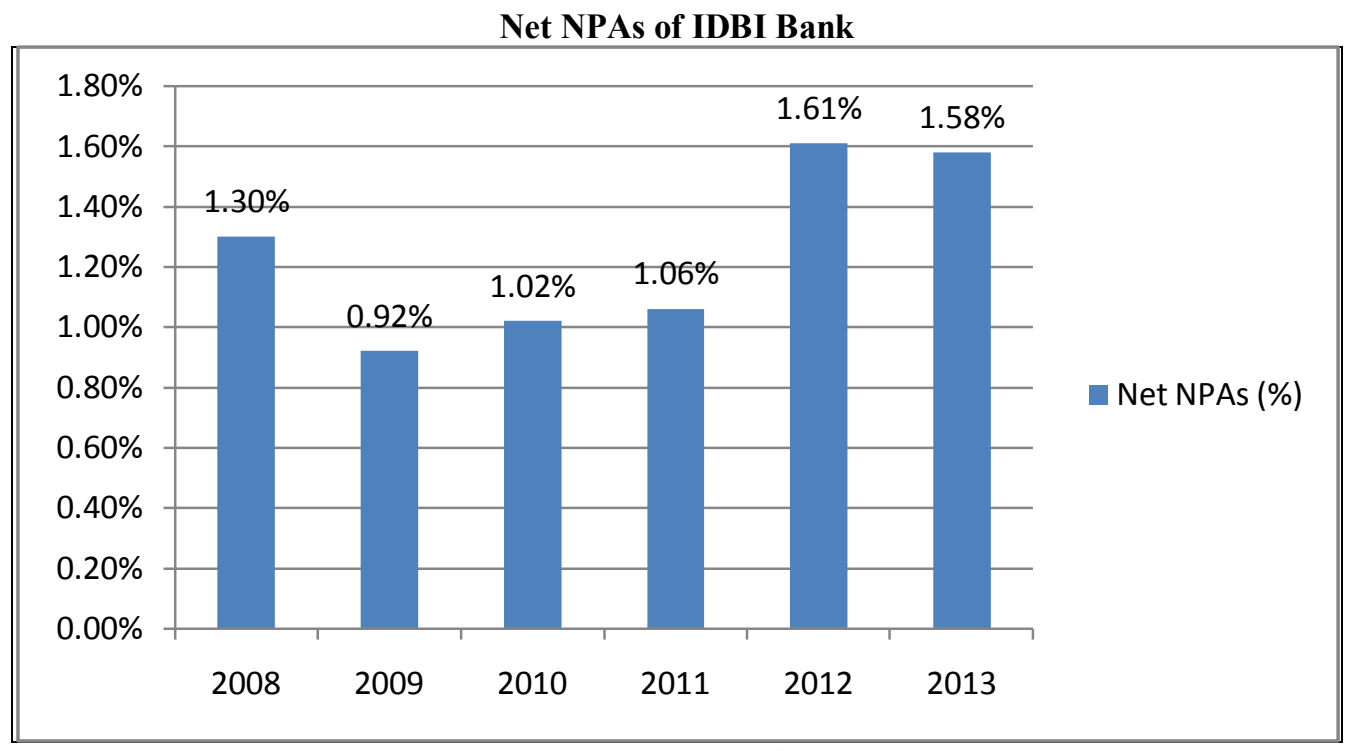

Table 1.1 (g) Net NPAs of IDBI Bank

\section{Source: IDBI Annual Reports 2008-13}

The net NPAs in the year 2013 have been recorded at $1.58 \%$. There is an improvement in the NPA level as it was $1.61 \%$ in the previous year (2011-12). Therefore, the NPAs have declined by $0.03 \%$ in the current year. Net NPAs were $1.30 \%$ of net advances in 2008 which declined to $0.92 \%$ in 2009 . The NPA level increased to $1.02 \%$ in 2010 . It further increased to $1.06 \%$ in 2011 . The NPA levels have been at low levels throughout the period of study meeting out the standards of maximum of $2 \%$ as per the RBI. It means that credit and risk management of IDBI bank has been effective during the period of study. 


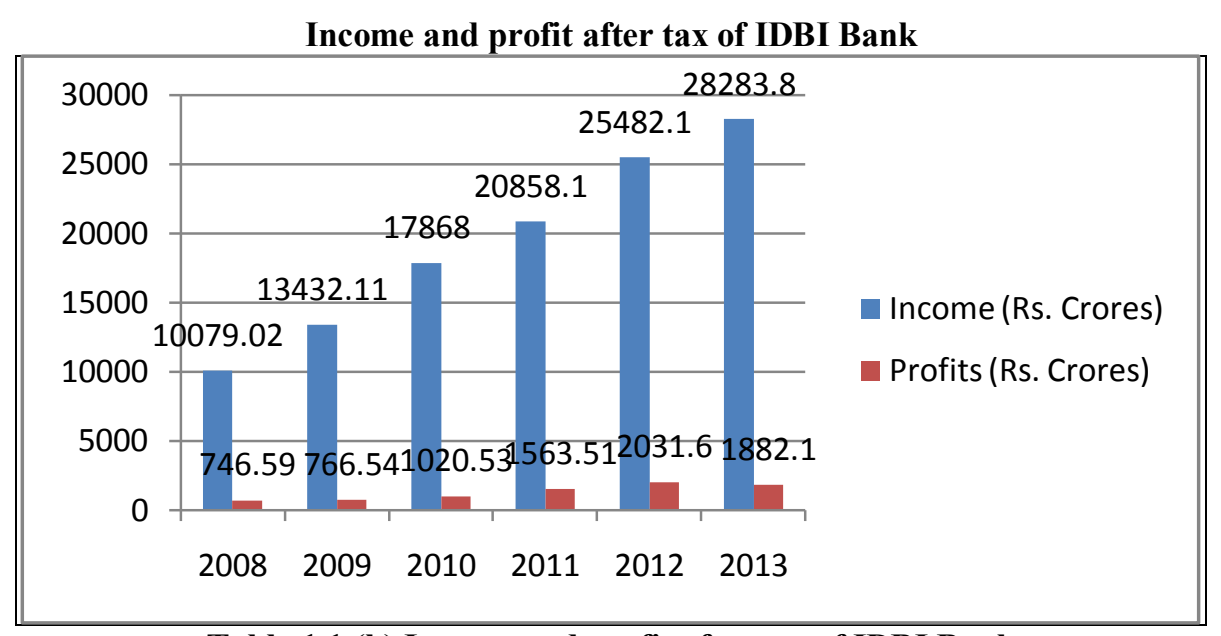

Table 1.1 (h) Income and profit after tax of IDBI Bank

\section{Source: IDBI Annual Reports 2008-13}

From the above table it can be observed that the total income of the Bank was Rs. 28,283.8 crores in the year 2012-13 against the Rs. 25,482.1 crores in the previous year (2011-12). The income has increased by Rs. $2,801.7$ crores in the existing year by $11 \%$. The earnings were Rs. $10,079.02$ crores in 2008 which increased to Rs. $13,432.11$ crores in 2009 . The earnings further increased to Rs. 17,868.00 crores in 2010 and increased to $20,858.10$ crore Rupees in 2011. During the period of study (2008-2013) the earnings have increased by $180.62 \%$ which is an impressive progress made by the bank.

The PAT in the year 2013 is recorded at Rs. 1882.1 crores as against Rs. 2,031.6 crores in the previous year. The profits of the Bank therefore have declined by Rs. 149.5 crores. In terms of percentage, this is a decline by $7.35 \%$. The PAT was 746.59 crore Rupees in 2008 which increased to 766.54 crores in 2009. The PAT further increased to 1020.53 crores in 2010. The growth in profits was again registered in 2011 with 1563.51 crores. The PAT has registered a positive growth during the period of study (2008-2013) except for the year 2013. The overall PAT has increased by $152.09 \%$ from 2008 to 2013 .

\section{Conclusion}

From the financial analysis of the IDBI Bankit can be observed that the bank has a robust financial position. After the liberalization period in 1991, IDBI Bank after transforming itself from a DFI to a bank in 2005 with its merger with its DFI arm IDBI, has withstood the problems of raising finance and maintaining its spreads in comparison to its peer DFI the IFCI. Over the years, IDBI has been raising finance by issuing bonds in the Indian debt market. This is largely due to sustained level of profitability and lower NPA levels due to better credit risk management by the bank.

\section{References}

[1]. Datt R. and Sundaram K.P.M., 2006: 'Indian Economy', S. Chand \& Company Ltd., New Delhi, 781.

[2]. Ahluwalia, M.S., 1993: 'India's Economic Reforms:The Future of Economic Reform', Oxford University Press: New Delhi. Economics 58, 187-214

[3]. Ahluwalia, M. S., 2000: 'Economic Reforms of States in Post-Reform Period', Economic and Political Weekly, 6 May,http://www. states forum.org/DATA/Economic\%20 Performance \% 20of\%20states-Montek.pdf

[4]. Annual Reports 2008-2013, RBI

[5]. Bhandari L, Dasgutpa S. and Gangopadhyay S., 2003: 'Development Financial Institutions, Financial Constraints and Growth: Evidence from the Indian Corporate Sector', Journal of Emerging Market Finance, Vol. 2, No. 1, 83-121.

[6]. Bhide, M G., Prasad, A. and Ghosh S., 2001: 'Emerging Challenges in Indian Banking', Munich Personal RePEc Archive, Paper presented at the Conference on Indian Economic Policy: Trade, Finance and Public Finance at Stanford University,June 01-02, 2001.

[7]. IDBI Annual Reports 2008-13. 